\title{
NOTE
}

\section{Size and priority at settlement determine growth and competitive success of newly settled Atlantic cod}

\author{
M. Tupper ${ }^{1, *}$, R. G. Boutilier ${ }^{1,2}$ \\ ${ }^{1}$ Department of Biology, Dalhousie University, Halifax, Nova Scotia, Canada B3H 4J1 \\ ${ }^{2}$ Department of Zoology, University of Cambridge, Cambridge CB2 3EJ, United Kingdom
}

\begin{abstract}
Research on the declining stocks of North Atlantic cod Gadus morhua has focused on the survival of planktonic larvae as a predictor of recruitment to the fishery. Very little is known of the ecology of benthic young-of-year cod, although it has been suggested that abundance of demersal $0+$ fish may be a better indicator of year-class strength than larval abundance. We studied settlement and growth of individual age $0+$ Atlantic cod in situ, using visual census and visual length estimation. Newly settled cod were siteattached and defended territories around a shelter site. Territory size increased exponentially with fish length. Growth and territory size were also determined by size at settlement and by priority; fish that settled largest/earliest grew more quickly and held larger territories than smaller/later settlers. Population dynamics of Atlantic cod may therefore be regulated in the early juvenile stage by post-settlement competition. Size at settlement, in addition to the timing of settlement. may determine the competitive success of an individual.
\end{abstract}

KEY WORDS: Atlantic cod - Settlement · Survival - Competition

The Atlantic cod Gadus morhua has long been the mainstay of the North Atlantic fishery. Over the past decade, research into cod recruitment variability has largely focused on survival of the planktonic larval stage. This approach stems from the assumption that populations of cod are 'recruitment-limited', that is, despite the prodigious fecundity of cod, stochastic planktonic processes limit the numbers of larvae available for settlement to suitable habitat (Doherty 1983, Victor 1983). According to this reasoning, population size will be below numbers set by available resources, and variation in adult abundance will directly reflect variation in the survival of pelagic larvae. An alterna-

\footnotetext{
- Present address and address for correspondence: Bellairs Research Institute of McGill University, St. James, Barbados, West Indies
}

tive theory, that of 'resource-limitation', states that populations of fish are regulated at or around a carrying capacity by competition for limited resources, primarily living space (Hunte \& Côté 1989). Thus, settlement, growth and survival of fish are density-dependent. These hypotheses have been tested extensively in coral reef fish systems, with the emerging view that they are extremes of a continuum, i.e that limitation of fish populations by density-dependent post-settlement interactions or by stochastic planktonic survival is a matter of degree (Forrester 1990, Jones 1990, Hunt von Herbing \& Hunte 1991).

To date, fisheries scientists have been largely unsuccessful in correlating abundance of eggs/larvae with abundance of adult Atlantic cod (Campana et al. 1989) Since cod take 3 or more years to reach harvestable size, this ichthyoplankton approach overlooks a large portion of their life history. Recent research on other North Atlantic species has pointed to early juvenile survivorship as an important contributor to year-class strength (Sogard 1992). The extremely high mortality rates typically associated with post-settlement juveniles are thought to be primarily due to predation. Many piscivores demonstrate size-selective predation concentrating on smaller size classes (Post \& Evans 1989a, Juanes 1994). In addition, overwinter survival of young-of-year fish in northern climates is generally higher in larger individuals (Post \& Evans 1989b, Malloy \& Targett 1991). Thus, availability of shelter and rate of growth are considered major determinants of early juvenile survivorship. Juvenile fish may therefore be expected to exhibit behaviours that tend to minimize the risk of predation while maximizing growth. However, little is known of the ecology of juvenile cod in their natural environment, since studies of this and other northern marine species have almost invariably been conducted by trawl analysis. While trawling pro- 
vides the advantage of covering a large area with relatively little effort, it cannot be used in shallow nearshore areas or areas of complex hard bottom, which small juvenile fish are likely to inhabit. In addition, trawling requires expensive gear and ship time, but provides no information on the growth and behaviour of individual fish. Visual census, however, is a mainstay approach to the study of settlement, growth and behaviour of tropical coral reef fish and has provided a wealth of information on these species. We therefore use in situ visual census and visual length estimation to describe the settlement, growth and behaviour of a population of young-of-year cod in St. Margaret's Bay, Nova Scotia, Canada.

Methods. The abundance of newly settled cod on Back Cove Reef in St. Margaret's Bay was estimated by visual census at roughly biweekly intervals from June through December 1991. Water temperature was recorded at each census. Visual censuses were conducted while snorkelling a $50 \mathrm{~m}$ transect line parallel to the shore, at a depth of 1.5 to $2.5 \mathrm{~m}$. Juvenile cod within $1 \mathrm{~m}$ of either side of the transect line were counted and their total lengths estimated to the nearest $5 \mathrm{~mm}$ using a clear plastic ruler fastened to the end of a $50 \mathrm{~cm}$ length of wooden dowel. The accuracy of this method was tested by visually estimating (to the nearest $5 \mathrm{~mm}$ ) the total length of individual fish while snorkelling, then immediately capturing the same fish and measuring it to the nearest $\mathrm{mm}$ with a plastic ruler. Accuracy decreased with increasing length of fish. Below $100 \mathrm{~mm}$ total length, the method was accurate to $\pm 3.9 \mathrm{~mm}$. Above $100 \mathrm{~mm}$, accuracy decreased to $\pm 5.7 \mathrm{~mm}$. The technique was facilitated by the tendency of juvenile cod to flatten themselves against depressions in the substrate and remain motionless while being measured. While more accurate measures may have been gathered by repeatedly capturing the fish, the process of capture became increasingly difficult as the fish grew larger and were able to swim faster. Newly settled fish were captured using anaesthetic (10\% solution of Quinaldine in seawater), marked by a specific pattern of fin clipping (allowing individual fish to be recognized and measured by visual estimation in subsequent censuses), and immediately returned to their capture site. Upon release, the fish invariably returned at once to their original shelter site. This procedure took less than 3 min per fish and was completed in situ, without removing the fish from the water.

Home ranges of 10 individual $0+$ cod were measured during $2 \mathrm{~h}$ snorkeling observations, in which the maximum distance moved in any direction from the shelter site was recorded on a 1:1000 scale drawing of Back Cove Reef. The actual area covered by the home range was then extrapolated from the area measured on the scale drawing. The home range of each individual was measured 5 times over the course of the study, allowing analysis of the effects of fish length on home range size. Growth rates of the same 10 individuals were calculated as the increase in total length divided by the number of days between successive measurements.

Results. Newly settled cod inhabited crevices in the reef substrate and remained site-attached, defending territories around their home site. These territories appeared to be feeding ranges, with the perimeters set by visual landmarks. Encounters between $0+$ cod along these boundaries generally resulted in aggressive interactions. In all cases where a visible size difference existed between the interacting fish, the larger individual succeeded in driving away the smaller. The area of each individual's territory was found to increase exponentially with the length of the occupant fish $\left(\mathrm{r}^{2}=0.95\right.$, $\mathrm{p}<0.001$; Fig. 1)

Seltlement of $0+$ cod occurred in 2 pulses, the first in late June and the second in late August (Fig. 2). Individuals from the first pulse of settlement were significantly larger than those from the second pulse ( $t$-test, $t=4.5, \mathrm{p}<0.05$ ). Moreover, individuals settling in late June, on a rising temperature curve, grew faster and remained larger than individuals settling in late August, on a falling temperature curve. Table 1 illustrates the temporal variation in the rank order of estimated total length of 10 individual $0+$ cod at Back Cove Reef. Size at settlement was a good predictor of growth rate $\left(r^{2}=0.69, p<0.01\right.$; Fig. $\left.3 a\right)$; individuals that were larger at settlement grew faster and remained larger throughout the study. In addition, prior residents ii.e.

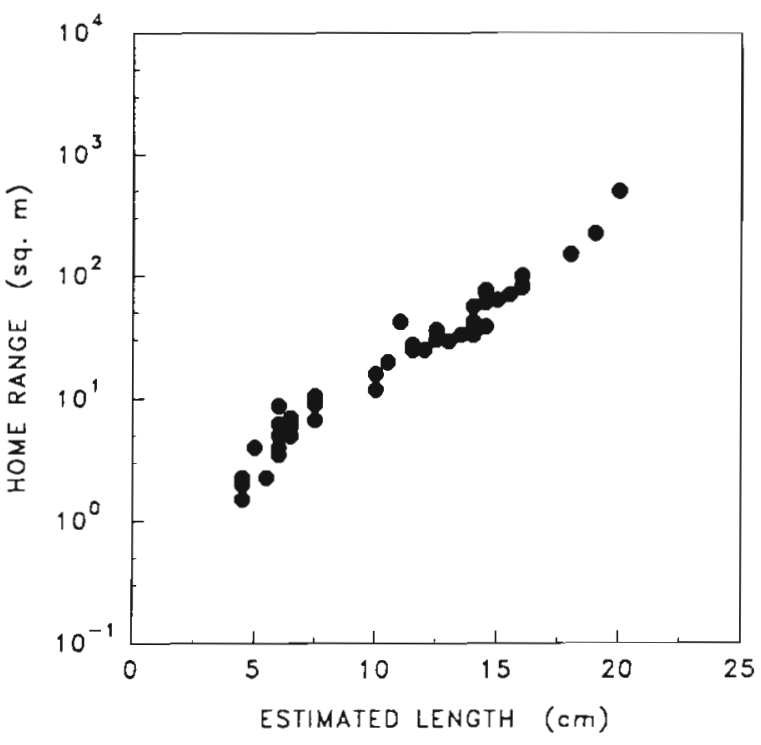

Fig. 1. Gadus morhua. Relationship of home range size to length of 10 individual $0+$ Atlantic cod measured at $2 \mathrm{wk}$ intervals during July to November 1992 
Fig. 2. Gadus morhua. Temporal change in water temperature and in estimated total length of 10 individual $0+$ Atlantic cod at Back Cove Reef, St. Margaret's Bay, Nova Scotia, from June to December 1991. Symbols represent individual fish; first appearance of a symbol indicates settlement of that individual

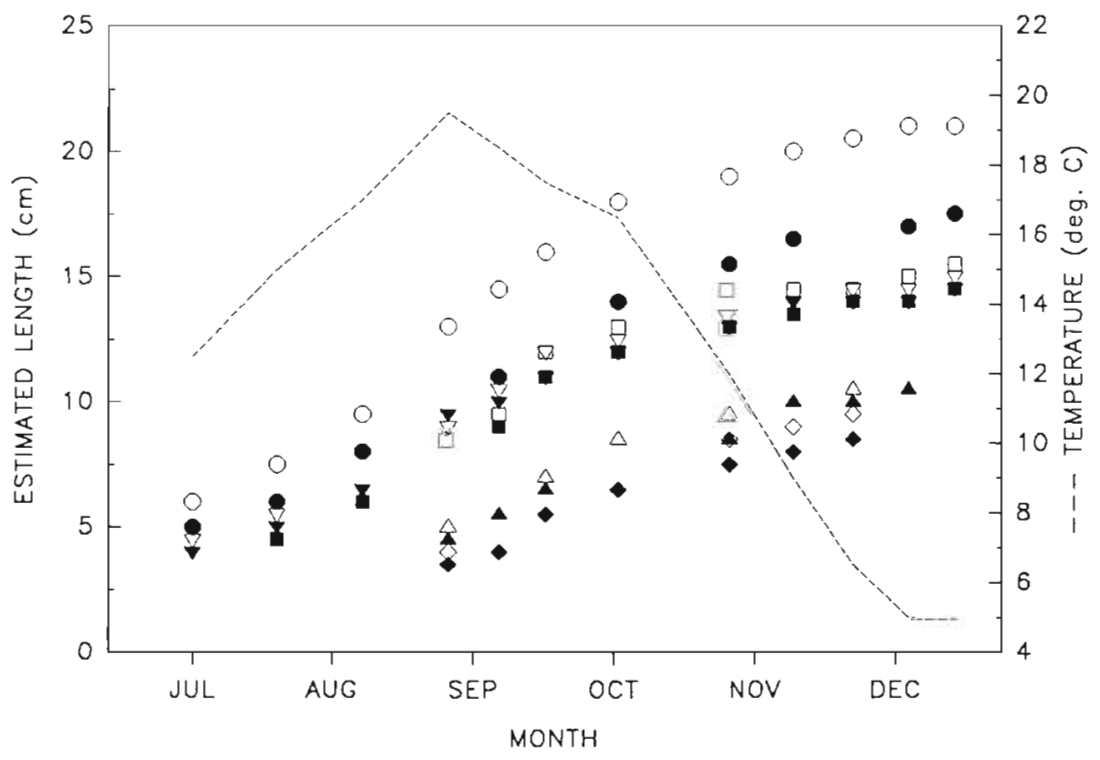

individuals settling to the sites in June) grew more rapidly than late-settling individuals ( $t$-test, $t=8.9, \mathrm{p}<$ 0.01 ; Fig. 3b). A strong positive relationship $\left(\mathrm{r}^{2}=0.82\right.$, $p<0.001$ ) was found between growth rate and size of home range (Fig. 3c), i.e. individuals holding the largest home ranges had the highest rates of growth.

Post-settlement growth rates of individual cod ranged from 0 to $2.27 \mathrm{~mm} \mathrm{~d} \mathrm{~d}^{-1}$ (mean $=0.71 \mathrm{~mm} \mathrm{~d}^{-1}$ ), increasing with temperature to a maximum of 0.65 to $2.27 \mathrm{~mm} \mathrm{~d}^{-1}\left(\right.$ mean $\left.=1.06 \mathrm{~mm} \mathrm{~d}^{-1}\right)$ at about $18^{\circ} \mathrm{C}$, above which growth rates appeared to decline (Fig. 4). Maximum growth of $0+$ cod occurred in late August, coinciding with the second pulse of settlement (Fig. 2). After August, growth rate declined steadily until December (mean $=0.33 \mathrm{~mm} \mathrm{~d}^{-1}$ for December). As temperatures decreased, $0+$ cod became more active and were observed swimming farther offshore from their home sites. By late December, at a temperature of about $5^{\circ} \mathrm{C}$, all cod had left the study area, presumably migrating to deeper, warmer water. At this point, $0+$ cod ranged from 130 to $200 \mathrm{~mm}$ in total length (Fig. 2) and may have been less dependent on the reef for shelter. Temperature might then have become a more significant factor influencing habitat selection of these fish.

Discussion. In this study, newly settled cod inhabiting a rocky reef established territories which they defended from all intruders. A size-specific social hierarchy existed, with the largest fish controlling the largest territories (Fig. 1) and having the fastest growth rates (Fig. 3a, c). Forrester (1990) and Tupper (1994) found similar hierarchies in 0+ humbug damselfish Dascyllus aruanus and cunner Tautogolabrus adspersus, respectively. They reported that growth rates were size-specific and that in no case did the growth of a smaller fish overtake that of a larger individual of the same population. The formation of such size hierarchies may be explained by asymmetric competition for food or by direct inhibition of growth through agonistic interactions, which reduce surplus energy available for growth (Forrester 1990, Tupper 1994). Shulman (1985) showed that dominance in intraspecific aggression in

Table 1. Gadus morhua. Rank order vs time of census for 10 individual $0+$ cod at Back Cove Reef. Fish are ranked from largest to smallest, i.e. 1 is largest, 10 is smallest. Tied ranks are averaged

\begin{tabular}{|c|c|c|c|c|c|c|c|c|c|c|c|c|}
\hline \multirow{2}{*}{$\begin{array}{c}\text { Fish no. } \\
1\end{array}$} & \multirow{2}{*}{$\frac{\text { June }}{1}$} & \multicolumn{2}{|c|}{ July } & \multicolumn{2}{|c|}{ August } & \multicolumn{2}{|c|}{ September } & \multicolumn{2}{|c|}{ October } & \multicolumn{2}{|c|}{ November } & \multirow{2}{*}{$\begin{array}{c}\text { December } \\
1\end{array}$} \\
\hline & & 1 & 1 & 1 & 1 & 1 & 1 & 1 & 1 & 1 & 1 & \\
\hline 2 & 2 & 2 & 2 & - & 2 & - & 2 & 2 & 2 & - & 2 & 2 \\
\hline 3 & 3 & 3 & 3.5 & 3 & 3 & 2.5 & 4 & 4 & 4.5 & 2.5 & 4 & 4 \\
\hline 4 & 4 & 4 & 3.5 & 2 & 4 & 4.5 & 5.5 & 5.5 & 4.5 & 4.5 & 5.5 & 5.5 \\
\hline 5 & - & 5.5 & 5.5 & 4 & 5 & 2.5 & 3 & 3 & 3 & 2.5 & 3 & 3 \\
\hline 6 & - & 5.5 & 5.5 & - & 6 & 4.5 & 5.5 & 5.5 & 6 & 4.5 & 5.5 & 5.5 \\
\hline 7 & - & - & - & 6 & - & 6 & 7 & 7 & 7.5 & 7 & - & - \\
\hline 8 & - & - & - & 7 & 7 & 7 & - & 8.5 & 7.5 & 8 & 7 & - \\
\hline 9 & - & - & - & 8 & - & 8 & - & 8.5 & 9 & 9 & - & - \\
\hline 10 & - & - & - & 9 & 8 & 9 & 8 & 10 & 10 & 10 & - & - \\
\hline
\end{tabular}



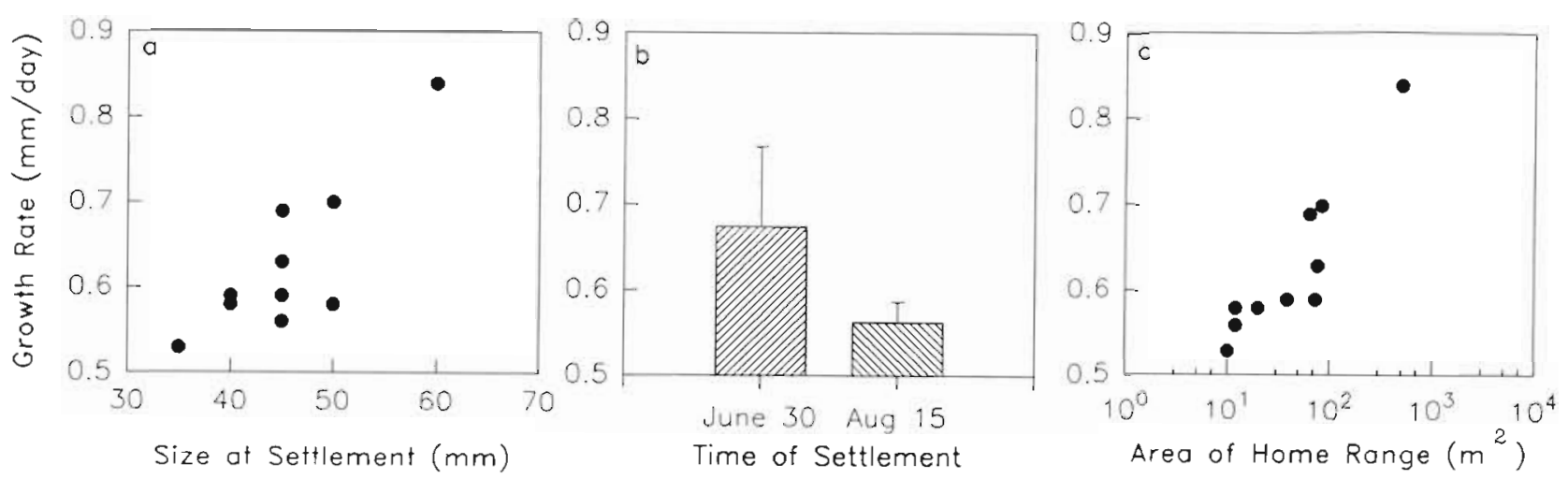

Fig. 3. Gadus morhua. Effects of (a) size at settlement, (b) priority in the timing of settlement, and (c) home range size on the growth rate of 10 individual $0+$ Atlantic cod

4 species of coral reef fish was determined by relative size, with larger individuals dominating in 95 to $98 \%$ of encounters. Hunte \& Côté (1989) found that average territory size of redlip blennies Ophioblennius atlanticus decreased by about $50 \%$ following recruitment of new individuals to the population, and that postrecruitment territory size was a function of fish length. They suggested that a decrease in available space following recruitment limited the size of territories.

Young-of-year Atlantic cod settle in many habitats other than reefs or rock ledges, including sand, gravel or cobble bottoms, seagrass beds, and macrophytic algal stands (Keats et al. 1987, Lough et al. 1989, Tupper \& Boutilier 1995). Fish behaviour is very plastic and the type of interactions observed on rocky reefs might not be expected in other habitats. For example, cod settling on sand bottoms cannot compete for nonexis-

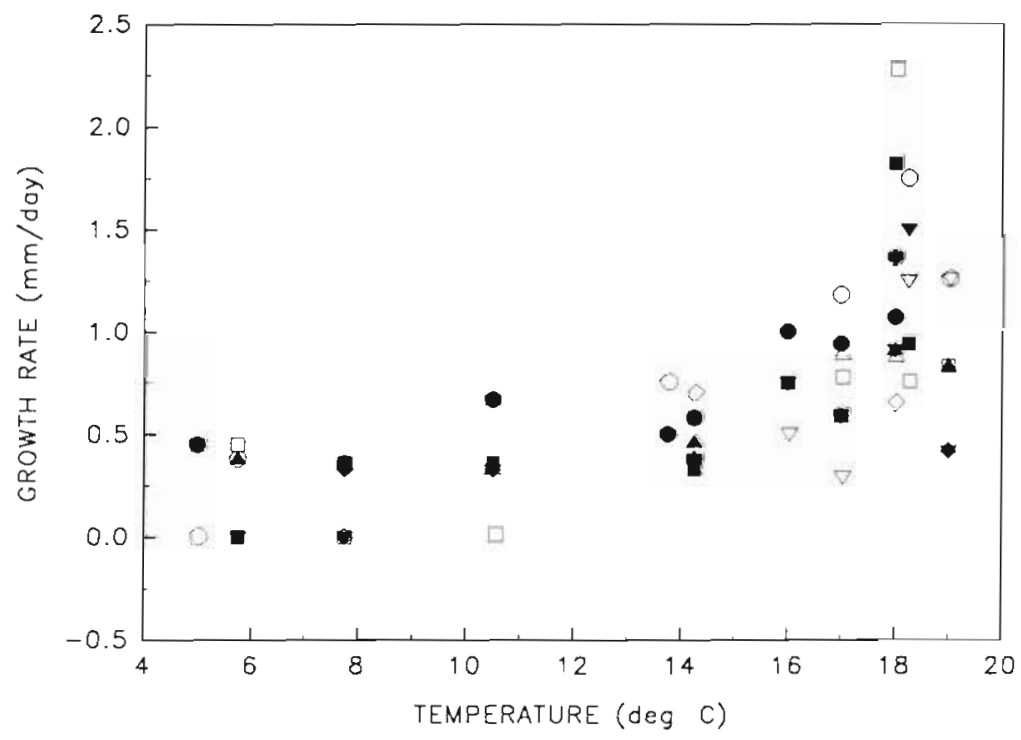

Fig. 4. Gadus morhua. Rate of growth of 10 individual 0+ Atlantic cod, plotted as a function of water temperature. Symbols represent individual fish. tent shelter sites and will generally school for protection (M. Tupper pers. obs.). Moreover, even in complex hard-bottom habitats, young-of-year cod appear to lose their site fidelity before their first winter, at which point they disperse into deeper waters (Tupper \& Boutilier 1992). However, since much of the Atlantic coast of Nova Scotia is characterised by rocky reefs and ledges, and because the first several weeks postsettlement are considered to be a 'critical period' in the survival of newly settled fish (Sale \& Ferrell 1988), we feel that the mechanisms discussed in this paper may be of great importance to the species, particularly to the inshore stocks along the Atlantic Canadian coastline.

Given the obvious competitive success of the larger, established July settlers over the late August cohort (Fig. 3b), it appears advantageous to $0+$ cod to settle as early and at as large a size as possible. Several species of marine fish are known to display a degree of plasticity in their larval duration, sometimes delaying transformation to the demersal phase until a suitable habitat is encountered or until environmental factors such as depth, current speed or illumination favour settlement (Victor 1982). For most species in which this behaviour has been documented, the delay in settlement is accompanied by a sharp decrease in larval growth rate, such that the size at settlement for these species is relatively fixed, typically varying from only 1 to $3 \mathrm{~mm}$ (Victor 1986, 1991, Cowen 1991). The result is a fish that settles later but not at a larger size. However, Cowen (1991) found that post-settlement growth rates of the temperate wrasse Semicossyphus pulcher were not affected by delaying settlement and therefore suggested that ex- 
tending the planktonic phase was not detrimental to this species. Given the results of the present study, a delay in settlement without a corresponding increase in size at settlement would clearly disadvantage $0+$ Atlantic cod. Cod, however, differ from most demersal marine fishes in that the larvae transform into a pelagic juvenile phase at 2 to 3 mo post-hatch (Lough et al. 1989). The length of time spent in this pelagic juvenile phase is variable and the transition from the pelagic to the demersal life stage appears to be a gradual process (Bolz \& Lough 1988), with the fish becoming more demersally oriented as they grow larger. It is possible that variation in individual growth rates of pelagic juveniles may lead to a broader range of sizes at settlement ( 30 to $60 \mathrm{~mm}$ TL in this study) than has been documented for other species.

The fact that $0+$ cod may compete for shelter sites indicates that shelter from predation is a potentially limiting resource and therefore that adult population size of cod is not determined solely by reproductive output and/or survival of the planktonic stage. High mortalities of young-of-year cod may result from density-dependent post-settlement interactions, mainly competition for shelter. Tupper \& Boutilier (1995) found that although settlement of $0+\operatorname{cod}$ to other sites in St. Margaret's Bay was not related to habitat complexity (i.e amount of available shelter), proportional survival of $0+\operatorname{cod} 1$ mo after settlement was highly correlated with habitat complexity. This suggests that patterns of distribution of $0+$ cod in St. Margaret's Bay result from post-settlement processes such as competition and predation, rather than reflecting the spatial pattern of settlement. Shulman et al. (1983) identified 2 types of 'priority effects', whereby the presence of one species (or conspecific cohort) in a habitat decreases the success of another. First, recruitment of 3 species of coral reef fish decreased significantly in the presence of a prior resident territorial pomacentrid. Second, prior settlement of a juvenile piscivorous lutjanid resulted in diminished recruitment of 2 juvenile prey species. Shulman (1984) also found that settlement and/or post-settlement survival of several coral reef fishes were strongly limited by the availability of shelter sites. Density-dependent distribution has also been demonstrated for adult cod (age groups $3+$ to $8+$ ) in the southern Gulf of St. Lawrence (Swain \& Wade 1993). Post-settlement processes will tend to be more important in those years/locations when settlement strength is high and the availability of suitable habitat is low. Conversely, when larval abundance is low, there may be insufficient settlement strength to saturate a habitat with $0+$ cod, and the importance of post-settlement competitive processes will decrease.

The mean growth rate of $0.71 \mathrm{~mm} \mathrm{~d}^{-1}$ is somewhat lower than Bolz \& Lough (1988) predicted for age 0+ cod on Georges Bank. Based on daily otolith increments, they estimated the mean growth rate to be 1.52 $\mathrm{mm} \mathrm{d}^{-1}$ for fish from 40 to $170 \mathrm{~cm}$ standard length. Maximum growth of $0+\operatorname{cod}$ in St. Margaret's Bay occurred in mid-August, when water temperatures were near maximum (approx. $18^{\circ} \mathrm{C}$ ). Intuitively, this would appear to be an extraordinarily high thermal growth optimum for a species that prefers a general range of 5 to $9^{\circ} \mathrm{C}$. However, surprisingly little is known of the effects of temperature on growth of juvenile Atlantic cod. Laboratory studies have found no thermal optimum for growth of $0+$ cod from Newfoundland in the range of 0.6 to $8.3^{\circ} \mathrm{C}$ (Brown et al. 1989). The warm-water growth peak demonstrated in this study may in part explain the late summer congregation of juvenile cod in warm, shallow inshore waters. Faster growth during the first several months may confer a physiological advantage to young-of-year fish. Many species survive overwinter on stored lipids, and survival is generally much higher in larger individuals (Henderson et al. 1988). The second settlement episode occurred in mid-August, coinciding with the time of peak growth. Settlement of fish during a period of enhanced growth may reduce the amount of time spent in the smaller and presumably more vulnerable early juvenile stages (Walsh 1987). However, in the population studied, the presence of prior resident $0+$ cod with established territories appeared to depress the growth of late settlers (Fig. 3b). This indicates that behavioural interactions may have equal or greater importance than physiological responses in determining growth rates of $0+$ cod. In St. Margaret's Bay, density-dependent growth has also been demonstrated for cunner Tautogolabrus adspersus (Tupper 1994). As with population density, the degree to which growth is regulated by density-dependent competitive interactions should vary as a function of the settlement strength and availability of suitable habitat.

In summary, these findings show that young-of-year Atlantic cod compete for shelter sites and surrounding territories, with the largest fish controlling the largest area and having the fastest growth rate. This indicates that given a sufficient settlement strength, populations of juvenile cod may be regulated by competition for limited shelter sites, with high mortality occurring in areas of low habitat complexity. Early settlement and large size at settlement confer a distinct competitive advantage to juvenile cod. If size at settlement is predetermined by some measurable factor, either genetic or physiological, then it may become possible to predict post-settlement survival and subsequent recruitment of cod. Growth of $0+$ cod appears temperaturedependent, with an unusually high thermal optimum; further experimentation is needed to clarify the effects of temperature on growth of this species. The inshore 
bays and coves in which $0+$ cod congregate in late summer provide warm temperatures, abundant shelter sites and abundant food. These inshore habitats or 'nursery areas' may serve to maximize growth and survival, and may be vital to the eventual recruitment of cod to the fishery.

Acknowledgements. We thank I. Hunt von Herbing and R. Conrad for assistance in the field. S. Kerr. I. Hunt von Herbing and 2 anonymous referees provided thoughtful reviews of the manuscript. Funding for this study was provided by a Natural Sciences and Engineering Research Council (NSERC) Postgraduate Scholarship to M.T. and by an operating grant from the NSERC programme Ocean Production Enhancement Network to R.G.B.

\section{LITERATURE CITED}

Bolz, G. R., Lough, R. G. (1988). Growth through the first six months of Atlantic cod, Gadus morhua, and haddock, Melanogrammus aeglefinus, based on daily otolith increments. Fish Bull. U.S. 86: 223-235

Brown, J. A., Pepin, P., Methven, D. A., Somerton, D. C. (1989). The feeding growth and behaviour of juvenile cod, Gadus morhua L., in cold environments. J. Fish Biol. 35: 373-380

Campana, S. E., Frank, K. T., Hurley, C. F., Koeller, P. A., Page, F. H., Smith, P. C. (1989). Survival and abundance of young Atlantic cod (Gadus morhua) and haddock (Melanogrammus aeglefinus) as indicators of year-class strength. Can. J. Fish. Aquat. Sci. 46: 171- 182

Cowen, R. K. (1991). Variation in the planktonic larval duration of the temperate wrasse Semicossyphus pulcher. Mar. Ecol. Prog. Ser. 69: 9-15

Doherty, P. J. (1983). Tropical territorial damselfishes: is density limited by aggression or recruitment? Ecology 64: $176-190$

Forrester, G. E. (1990). Factors influencing the juvenile demography of a coral reef fish. Ecology 71: 1666-1681

Henderson, P. A., Holmes, R. H. A., Bamber, R. N. (1988). Size-selective overwintering mortality in the sand smelt, Atherina boyeri Risso, and its role in population regulation. J. Fish Biol. 33: 221-233

Hunt von Herbing, I., Hunte, W. (1991). Spawning and recruitment of the bluehead wrasse. Thalassoma bifasciatum, in Barbados. Mar. Ecol. Prog. Ser 72: 49-54

Hunte, W., Côté, I. M. (1989). Recruitment in the redlip blenny Ophioblennius atlanticus: is space limiting? Coral Reefs 8: 45-50

Jones, G. P. (1990). The importance of recruitment to the dynamics of a coral reef fish population. Ecology 71 : $1691-1698$

Juanes, F. (1994). What determines prey size selectivity in piscivorous fishes? In: Stouder, D. J., Fresh, K. L., Feller, R. J. (eds.) Theory and application in fish feeding ecology. Belle W. Baruch Library in Marine Sciences, 18. Univ. S. Carolina Press, Columbia, p. 79-100
Keats, D. W., Steele, D. H., South, G. R. (1987). The role of fleshy macroalgae in the ecology of juvenile cod (Gadus morhua L.) in inshore waters off eastern Newfoundland. Can. J. Zool. 65: 49-53

Lough, R. G., Valentine, P. C., Potter, D. C., Auditore, P. J. Bolz, G. Z., Neilson, J., Perry, R. I. (1989). Ecology and distribution of juvenile cod and haddock in relation to sediment type and bottom currents on eastern Georges Bank Mar. Ecol. Prog. Ser. 56: 1-12

Malloy, K. D., Targett, T. E. (1991). Feeding, growth and survival of juvenile summer flounder, Paralicthys dentatus: experimental analyses of the effects of temperature and salinity. Mar. Ecol. Prog. Ser. 72: 213-223

Post, J. R., Evans, D. O. (1989a). Experimental evidence of size-dependent predation mortality in juvenile yellow perch. Can. J. Zool. 67: 521-523

Post, J. R., Evans, D. O. (1989b). Size-dependent overwinter mortality of young-of-the-year yellow perch (Perca flavescens): laboratory, in situ enclosure, and field experiments. Can. J. Fish. Aquat. Sci. 46: 1958-1968

Sale, P. F., Ferrell, D. J. (1988). Early survivorship of juvenile coral reef fishes. Coral Reefs 7: 117-124

Shulman, M. J. (1984). Resource limitation and recruitment patterns in a coral reef fish assemblage. J. exp. mar. Biol. Ecol. 74: 85-109

Shulman, M. J., Ogden J. C., Ebersole, J. P., McFarland, W. N., Miller, S. L., Wolf, N. G. (1983). Priority efferts in the recruitment of juvenile coral reef fishes. Ecology 64: $1508-1513$

Sogard, S. M. (1992). Variability in growth rates of juvenile fishes in different estuarine habitats. Mar. Ecol. Prog. Ser. 85: $35-53$

Swain, D. P., Wade, E. J. (1993). Density-dependent geographic distribution of Atlantic cod (Gadus morhua) in the southern Gulf of St. Lawrence. Can. J. Fish. Aquat. Sci. 50: $725-733$

Tupper, M. (1994). Settlement and post-settlement processes in the population regulation of a temperate reef fish: the role of energy. Ph.D. thesis, Dalhousie Univ., Halifax

Tupper, M., Boutilier, R. G. (1992). Settlement and growth of age 0+ cod (Gadus morhua) in St. Margaret's Bay, Nova Scotia. Can. Tech. Rep. Fish. Aquat. Sci. 1890: 89-90

Tupper, M., Boutilier, R. G. (1995). Effects of habitat on settlement, growth and post-settlement mortality of Atlantic cod (Gadus morhua). Can. J. Fish. Aquat. Sci. 52: in press

Victor, B. C. (1982). Daily otolith increments and recruitment in two coral-reef wrasses, Thalassoma bifasciatum and Halichoeres bivittatus. Mar. Biol, 71: 203-208

Victor, B. C. (1983). Recruitment and population dynamics of a coral reef fish. Science 219: $419-420$

Victor, B. C. (1986). Delayed metamorphosis with reduced larval growth in a coral reef fish. Thalassoma bifasciatum. Can. J. Fish. Aquat. Sci. 43: 1208-1213

Victor, B. C. (1991). Settlement strategies and biogeography of reef fishes. In: Sale, P. F., (ed.) The ecology of fishes on coral reefs. Academic Press, San Diego, p. 231-260

Walsh, W. J. (1987). Patterns of recruitment and spawning in Hawaiian reef fishes. Environ. Biol. Fish. 18: 257-276

Manuscript first received: January 4, 1994

Revised version accepted: November 18, 1994 